\title{
RADICALISM IN THE PERSPECTIVE OF ISLAMIC-POPULISM Trajectory of Political Islam in Indonesia
}

\author{
Wasisto Raharjo Jati \\ Indonesian Institute of Sciences, Jakarta - Indonesia
}

\begin{abstract}
This article aims to analyze radicalism movement in Indonesia from Islamic-Populism perspective. In various academic studies about Islam, radicalism is perceived as an act of violence and terrorism. However, the study of radicalism was not always generating both premises. Populism sees many aggressive measure perpetuated by Muslims against the authoritarian regime is also a source of radicalism. Likewise, the absence of Muslim representation in formal politics has resulted in violence. In Islamic countries, global caliphate and/or implementation of sharia, which have been claimed as the purpose of radical Muslims, actually is the strategy to free themselves from the authoritarian forces. This article will examine deeper onto the dynamics of power of populism within radical groups in Indonesia. This article argues that radical Islamism is deeply connected to local and global histories of Islamist movements. Through the perspective of Islamic-populism, it is found out that radicalism emerged from the spirit of liberation to free Muslims from economic inequality and political marginalization.
\end{abstract}

Keywords: Radicalism, Islamic-populism, political Islam

\section{Introduction}

The term Islamic-Radicalism in Indonesia is debatable. This is because there is no consensus between Islamic scholars in defining this term. In many Islamic studies, there are two mainstream perspectives developed in analyzing radicalism. The first mainstream is a security oriented approach and then a structural-oriented approach. The security approach mainstream analyses radicalism primarily concerned 
with issues of terrorism and violence ${ }^{1}$. Both issues inherited in majority research among Islamic scholars such as Saiful Mujani, Ahmad Syafi'i Maarif, and Azyumardi Azra. In his book titled Muslim Demokrat, Mujani argued that there is an interconnectivity between external influence from Middle East who has brought Pan-Islamism, Muslim Brotherhood, and global caliphate and Muslims in Indonesia ${ }^{2}$. Those ideas are established in contemporary Islamic organization like Jamaah Islamiyah, Jamaah Ansarut Tauhid, Majelis Mujahidin Indonesia, and many others. Meanwhile, Azra and Ma'arif agree with Mujani's thesis in concluding that Islamic trans-national movement has great influence to idea for organizing Islamic movement in Indonesia. Furthermore, Maarif even mentioned that Wahhabism plays a significant role and in fact becomes a role model in creating and converting Muslims in Indonesia into terrorists ${ }^{3}$.

On the other hand, the structuralist-oriented approach analyzes radicalism in Indonesia by arguing that it is rooted from poverty problem in society. This is because inequality and marginalization in economic and social aspects has grown wider within society. In this mainstream, it is clear that the rich people become richer and the poor people become poorer and this condition has made easier for poor people to be radicalized. Thus, Islamic militancy is a response to poverty or impoverishment. Indonesia is not alone in this case. Many other countries also are hotbeds of militant Islam. The point is that militant Islam tends to surge in countries experiencing disillusionment, poverty and despair. Therefore, to reduce militancy is simply by improving economic condition and addressing economic inequality. The roots of Islamic radicalism must be looked for outside the religion, in the real world of cultural despair, economic decline, political oppression, and spiritual turmoil in which most Muslims find themselves today. In the case of the Middle East, many Islamic organizations also stress radicalism as a response towards political oppression and economic inequality. Hassan Al-Banna, the founder of Muslim Brotherhood in Egypt emphasized characteristic of political

1 Rohan Gunaratna, Inside Al Qaeda: Global Network of Terror (New York: Columbia University Press, 2002), p. 65.

2 Saiful Mujani, Muslim Demokrat, Islam, Budaya Demokrasi, dan Partisipasi Politik di Indonesia Pasca-orde Baru (Jakarta: Gramedia, 2007), p. 45.

3 Abdurrahman Wahid, Ilusi Negara Islam (Jakarta: Maarif and Wahid Institute, 2011), p. 74. 
movement in Muslim Brotherhood as anti-political oppression perpetuated by the regime that, in their opinion, collaborating with western bourgeoisie. ${ }^{4}$ The term "radical" needs careful definition because this term is very sensitive and multi-interpretative. The term "radical" is often associated with disagreement or terrorism that cornered Islam as universal religion. In this, paper, I explore Islamicradicalism using three analysis model. First, they believe that the Qur'an and Sunnah must be implemented literally by Muslims and this means purity from any interpretation of Islamic scholars and priests who traditionally hold authority in interpreting the Qur'an and Sunnah. Second, their point of views about Islamic teaching is very conservative particularly when it is used as the basis for rebuilding society and the state. Three, they give legitimation for their violent action in achieving their goals; building Islamic state and global caliphate.

This paper intends to examine the characteristics of IslamicRadicalism in Indonesia by using populism paradigm. It particularly focuses on the trajectory of political Islam in Indonesia from the political oppression and stereotyping perpetuated by New Order regime on Muslims to the rise of political Islam in the so called Era Reformasi. It argues that there are two problems faced by Muslims in Indonesia that fuel Islamic radicalism, namely the political oppressions by ruling regime and re-colonialization by the United States with the banner of "war against terrorism".

\section{Islamic-Populism as Response of Authoritarian Regime: Conceptual Framework}

Populism is understood here as a response to issues related to oppression of power and inequality of economic by authoritarian regime $^{5}$. The notion of populism itself has a relatively long history and began to be used to describe leadership in Latin America that has problems with inequality issues due to its overly expansive macroeconomic policies. The term populism then is used in Asia after 1997 where there was a raise of people's resistance towards the authoritarian governments and is caused by the economic crises. In

\footnotetext{
${ }^{4}$ Michael Fischer, "Islam and the Revolt of Petit Bourgeoisie," Daedalus, Volume 111, Issue 1 (1982), p. 105.

5 Margaret Canovan, Populism (New York and London: Harcourt Brace Jovanovich, 1981), p. 5.
} 
other words, populism is a political philosophy which supports the rights of people in their struggle against the privileged elites. In this paper, I use a simple definition of populism. Here, populism is defined as the resurgence of people power to achieve the goal that is establishing a democratic state replacing the authoritarian government such as New Order regime.

In general, democracy is understood and accepted as an antithesis to authoritarianism and it is considered as alternative form of state. However, in Indonesian political context, I see that democracy has not yet generally been accepted as some Islamist groups who insist the concept of an Islamic state as an ideal state in Indonesia. When we discuss Islamic populism then it is defined as a response to the oppression on Muslims perpetuated by the authoritarian regime that causes hatred to the state ${ }^{6}$. Historically, Islamic-populism can be traced from the state or government suppression of some Muslim elites right after the independence. ${ }^{7}$ Actually, the history of political root of Islamic populism can be traced back in the Middle East particularly Egypt and Turkey. Similar to Indonesia, the social base of organized Islam in both countries was influenced by the rise of Leftist tendencies in society. However, this interrelation between Islam and Leftist tendencies requires a more comprehensive interpretation and further clarification. First, Islamic populism has to be distinguished from the populism of rulers and states (Peronist populism, Kemalist populism, etc.). Second, Islamic populism is not another variant of clientelist 'populism' which is based on patronage politics.

The emergence of Leftist in the Middle East is related to the state's neo-liberal economic policies that created conducive economic conditions and an emerging transnational financial networks wherein Muslim bourgeoisie evolved out from the arena. Populism in Islamism concept is defined as "ideology of liberation" that consistently fight for redistribution of resources from dominant groups to subordinate groups. So, the emergence of Islamic populism is caused by the fact that Muslim bourgeoisie were marginalized and disadvantaged by the rapid development of the new layer of capitalists due to the neo-liberal policies. That condition also resulted in a mass migration from rural

${ }^{6}$ Vedi R. Hadiz, "Indonesian Political Islam: Capitalist Development and the Legacies of the Cold War," Journal of Current Southeast Asian Affairs, Volume 30, Issue 1 (2011), p. 10.

${ }^{7}$ Ibid. 
areas to the urban areas looking for better jobs and access to social services. This condition leads to riots among Muslims especially the middle class and the puritans struggling for economic justice for all.

In the case of Turkey, most religious movements are actually responses to modern problems such as capitalist exploitation and totalitarian authoritarianism. As such, religious movements turn out to tend more on actively creating modernism and their own critic rather than preserving the tradition. Turkey underwent two dominant challenges; Islam and the relation to democracy as well as Islam that is perceived as incompatible to capitalism. In the case of Turkey, one sees the evolution of an understanding of Islam that is both entrepreneurial and capitalist-oriented. The rise of a Muslim bourgeoisie is a challenge to the relationship between Islam and capitalism as one of incompatibility and antagonism. When Mustafa Kemal Ataturk came to power in 1923, he launched "a New Turkey" as a modernization project by adopting western values to substitute Islamic values that are attributed by him as barbarian and not supportive for the development of Turkey. Following that, he implemented the policy well known as "the six arrows "(Alt $O k$ ). The first principle is republicanism principle (cumburiyetcilik). Here, Turkey accepted parliamentary democracy system led by president or prime minister; not by sultan or caliphate. The second principle is nationalism principle (milliyetcilik) which means that citizenship is not determined by a particular religion or sect. Third principle is statehood principles (devletcilik) which means that the state have full authority in managing economic life and have rights to do intervention in economic area for public interest. The fourth principle is populism principles (balkcllk) which is defined as supremacy of human rights protection and equality of all people before the law. The fifth principle is secularism (laiklik). The last principle is evolutionism principle (inkilapcillk) $)^{8}$.

In this context, the development of a capitalist modern Turkey which is based on secular regime is believed as a threat for Islam. That time, Islamists are branded as backward. In addition, the sharia system is alleged as the backwardness source for Turkey's bad name of "The Sick man of Europe". The secular regime also campaigned what they call as "enlightened Islam". The jargon, enlightened Islam, is campaigned as Islam that is liberated from traditional Arabic values. In

8 Cihan Tugal, "Islamism in Turkey: beyond Instrument and Meaning," Economy and Society, Volume 31, Issue 1 (February 2002), p. 90. 
1998, "enlightened Islam" got resistance and challenges from puritans and leftists. They challenged this definition and even accused the capitalist and the secular regime as the ones who were backward. Furthermore, they also argued that the poverty and marginalization of majority of Islamist was also because they were excluded by the state and the import-substitution policies. They claimed that the regime was always in favor of a secular-oriented and big city-based bourgeois group as the carrier of its modernization projects and tended to marginalize Islamist in economic area. This condition then led to conformity of resistance from those Islamists in Turkey by establishing Islamist party as a vehicle for struggling for people who were marginalized by capitalism and the non-populist state policy. ${ }^{9}$ It is said that the party is the way to struggle but in a way also is 'peaceful' adaptation to the way capitalism and modernism works. The Justice Democratic Party (JDP), the Islamist party, defines itself as the one voicing the marginalized people and what they call as subaltern Islam. Since then, justice becomes a main issue of this party to advocate economic improvement of the Islamist and alleviate them from poverty.

Justice also becomes main issue that carried the Egyptian Muslim Brotherhood (al-Ikhwan al-Muslimun) in their political activity. This movement struggled for economic inequality for Muslims who had been marginalized by the military-backed regime. Egypt under Nasser had tendencies to applying socialism and Arab nationalism as foundation of the state in opposing Muslim Brotherhood's idea of Islamic state. As a result, Muslim Brotherhood suffered from political isolation from the regime including imprisonment of their leaders and cadres. Meanwhile, during presidency of Anwar Sadat, Egypt was deemed too liberal by issuing a policy to liberalize economic sector. In addition, after the Camp David peace accord, he was accused of being pro-Jewish and later established diplomatic ties with Israel who had been become old enemy for Muslim Brotherhood. That condition was triggering economic disparity between Muslims and Coptic Christians wherein the Copt got preferential treatment from the government. The rise of Muslim Brotherhood in Egypt is often said as a more political activity. It is fundamentalist movement as it intends to establish

9 Olaf Schumann, "Jihad for Whom? The Radicalization of Religion as a Response to Political Oppression: From Turkish to Indonesian Islam," Journal of Indonesian Islam, Volume 2, Issue 2 (December 2008), p. 248. 
Islamic state in Egypt. Still, beyond that reason, the rise of Muslim Brotherhood is mainly due to economic equality movement based economic justice of Muslims ${ }^{10}$.

Meanwhile, in Indonesian context, the New Order period has played an important part in the emergence of Islamic populism. This is due to the fact that Islam came as a representation of populism movement against the authoritarian regime that is based on capitalist modernization. Basically, there is a number of factors that plays role and influences in the emergence of Islamic populism. The first is the fluctuation in relationship between state and Muslims in Indonesia during the New Order era. The second is role played by political Islam as a major articulator in social justice issues in relation to the social contradictions associated with rapid capitalist development in the late twentieth century. The third is the long phase of authoritarian capitalist development under New Order regime that is considered as the fertile ground of the so called 'Islamic radicalism' in Indonesia. ${ }^{11}$ The revival of middle-class oriented political Islam is the one major development in a state-society relation in the late New Order period. In addition, the resurgence of populist Islam based political power in Indonesia's postNew Order era is characterized by the young Muslim generation began to significantly speak about the need for a greater role for Islam in domestic politics and foreign policy making. ${ }^{12}$ In addition to that, the rise of Islam populism is also indicated by the emergence of proliferation of the paramilitary wings associated with Islamist organizations. These include Laskar Pembela Islam (LPI - Defenders of Islam Militia); Laskar Jihad (LJ - Jihad Militia); Laskar Mujahidin Indonesia (Indonesian Mujahidin Militia) and Jemaah Islamiyah (JI Islamic Community). Many of these groups have roots in the Islamic militias of Indonesia's independence struggle. Yet, their current activities owe more to the tutelage of hadrami (Indonesians of Yemeni

10 Malika Zeghal, "Religion and Politics in Egypt: The Ulama of Al-Azhar, Radical Islam, and The State," International Journal of Middle East Studies, Volume 31, Issue 3 (August 1999), p. 380.

11 Ibid.

12 Bob Hadiwinata, Democracy in Indonesia: The Challenge of Consolidation (New York: Nomos Publishers, 2007), p. 380. 
descent) who fought alongside the mujabidin in Afghanistan in the late 1980s. ${ }^{13}$

\section{The Genesis of Indonesian Political Islam and Islamic- Radicalism in Indonesia}

According to Van Bruinessen, Islamic radicalism in Indonesia can be traced back from the emerging struggle for independence. Here, Islam developed three major political responses to and within the emerging national project. ${ }^{14}$ These were the traditionalist Sunni Islamic organization, Nabdlatul Ulama (NU - the Awakening of Ulama), the modernist Islamic political party, Masjumi (Council of Muslim Organizations) and the militant Islamist movements, Darul Islam (DI Home of Islam) and Tentara Islam Indonesia (TII - Indonesian Islamic Army). After Indonesia became independent from the Dutch colonial rule in 1945, the strained conflict began between Islamist and more secular forces concerned the question of whether Indonesia should become an Islamic state. The Islamists favored the implementation of sharia and state that in the constitution and making Indonesia become an Islamic state. Unsurprisingly, the proposal for Islamic state is rejected by secular force fearing the consequence that if Indonesia becomes an Islamic state, Christian majority in Eastern Indonesia would not want to integrate or unite in one nation. The Idea of "religious states" then becomes "middle way" to bridge aspirations from both the secular group and the Islamist group. Nevertheless, it turns out that not all Islamists accepted the "middle way" that is the religious state becomes the foundation in the constitution. The minority of Islamists even started rebellion with the goal to establish an Islamic state (Negara Islam) through military force. The so-called Darul Islam movement eventually managed to proclaim the establishment of Islamic rule in parts of West Sumatra, West Java, and South Sulawesi but these were eventually diminished by the central government after a decade- long civil war. ${ }^{15}$

13 Giora Eliraz, Islam in Indonesia: Modernism, Radicalism, and the Middle East Dimension, (Sussex: Sussex Publishers, 2004).

14 Martin van Bruinessen, "Genealogies of Islamic Radicalism in post-Suharto Indonesia," South East Asia Research, Volume 10, Issue 2 (2002), p. 125.

15 Greg Barton, "The Historical Development of Jihadi Islamist Thought in Indonesia," in Scott Helfstein, Radical Islamic Ideology in South East Asia (New York: South East Asia Project, 2011), p. 38. 
When Soeharto came to power after a bloody massacre in 1965, he saw Islamism become one of potential sources of radicalism and opposition to his government. This is a significant potential threat especially considering that the New Order really emphasized the stability of power as the foundation for its continuance. As an anticipation, the New Order regime produced several policies to eliminate the possibility of political instability; policies that were categorized by many Islamists as anti-Islam. The political Islam is being stigmatized to the extent where people perceived Islam as "political enemy number two" after communism. The Regime wishes to position Islamists as periphery actors in Indonesia's political life. Islamists are being marginalized by restricting the use of Islamic symbols and terms as well as limiting the number of Islamic parties. ${ }^{16}$

In 1973, New Order began to do what some call as de-politization of Islam by enforcing all Islamic political power to merge in one party; The PPP (Partai Persatuan Pembangunan - United Development Party). This party is supposed to serve function as "representation" for Islamists in politics. Yet, history shows that PPP experienced many difficulties and is mostly caused by the regime's continuous efforts to weaken the party with the "floating mass policy". This policy restricts political parties to establish their representative offices in districts or villages.

The Regime also uses another strategy to keep their eyes on the Islamists by establishing CSIS (Centre for Strategic and International Studies) in the 1970s, a think-tank institution under direct rule from General Ali Moertopo. This comes back to the fact that Islamists are seen as a threat as they have tendencies to oppose the regime. In this construction, being radical is defined and pictured as negative or simply 'the Bad Islam' while on the contrary being moderate is pictured as positive or 'the Good Islam'. The New Order also began to enforce Pancasila (The Five Principles) as the sole principle to all Islamist organizations. Here, Nahdlatul Ulama and Muhammadiyah, the two largest Muslim organizations in Indonesia accepted Pancasila as their sole principle. This position was followed by many other Islamic organizations. There is, though, a minority of Islamist like Abdullah Sungkar and Abubakar Ba'asyir, allegedly accused as the founders of Jemaah Islamiyah (JI), insisted to stick to their idea to

${ }^{16}$ Felix Heiduk, "Between a Rock and a Hard Place: Radical Islam in Post-Suharto Indonesia," International Journal of Conflict and Violence, Volume 6, Issue 1 (2012), p. 31. 
establish Islamic state in Indonesia. ${ }^{17}$ Nevertheless, JI had very little political influence because the New Order Regime heavily repressed the political Islam

Here, the so called "Komando Jihad" was created by Soeharto's regime to stigmatize "Islamic extremist" and Islamic movement. Soeharto regime legitimized their authoritarian politics of the New Order through the state-led development strategies. The Regime argued that they would not allow any political instability caused by many possible groups especially the Islamist movement as it would likely jeopardize the economic growth as well as the stability of power. ${ }^{18}$

In addition to that, Soeharto regime also created what is called as "Komando Jihad". The creation is aimed at showing how the "radical Islam" does pose a real threat. This discourse about Komando Jihad is fabrication of the regime and it shows how the regime exploits the notion to depict Islamists to the extent that they are as dangerous as communism as represented by the Indonesian Communist Party (Partai Komunis Indonesia). The regimes raise rumors that Komando Jihad are derived from pesantren (Islamic Traditional Boarding School) where they establish connection and network with mujahedeen in Afghanistan or the Middle East. "Komando Jihad" was also depicted in New Order's propaganda as an underground organization with the intention of seizing power by violence and establishing Islamic state in Indonesia. The famous incident in relation to Komando Jihad is the Hijacking of a plane that took place in Thailand's Dong Muang Airport in 1981. This was when Garuda Indonesia was hijacked by unknown people who then were said as the radical Islam terrorists. All passengers are the hostages and the flight route was forced to reroute from Medan to Bangkok. The hijacking was then overcome by Indonesian Special Armed Force. All mainstream international media appreciated the Indonesian government for successfully saving the plane from "terrorists". At the same time, Soeharto's regime accused the radical Islam for those behind the incident; they even exploited

17 Greg Barton, Indonesia's Struggle: Jemaah Islamiyah and the Soul of Islam (Sidney: University of New South Wales Press, 2004), p. 30.

18 Anies Rasyid Baswedan, "Political Islam in Indonesia - Present and Future Trajectory," Asian Survey, Volume 44, Issue 5 (2004), p. 675. 
that incident as propaganda ${ }^{19}$. "Komando Jihad", again, is used as a vehicle to depict Islam as having "hard-liners" and that they are terrorists. The propaganda then led to a heated tension between the state and Islamists and reached the peak in 1984 when many people demonstrated the state's treatment on political Islam with the famous Tanjung Priok incident. The incident happened in 12 September 1984 in Tanjung Priok Jakarta where several people who are accused for giving anti-government speech at Rawa Badak Mosque Tanjung Priok were arrested. There was also an anti-government demonstration held in the Tanjung Priok port area at North Jakarta. The participants were protesting against the policy requiring all organizations to adopt Pancasila as the sole ideology. They were then encircled by security forces that opened fire on the demonstrators. Survivors claimed that several hundred people were killed during the incident.

After the Incident, the government was blamed because several hundred people become victim. The regime worried Islamist would take revenge after the incident and cause riots. Soeharto was fully aware of the high potential of chaotic condition in the future and how this would potentially jeopardize the stability of power of his regime. Here, some changes start to take place. From the late 1980s to the 1990s, he changed his policy in order to build a stronger political coalition with Islam by introducing an Islamization strategy. This strategy includes the accentuation of Islamic symbols in public discourse and the accommodation of religious socio-political powers. In so doing, the Soeharto's regime introduced the bill on Islamic Court in 1989, Islamic sharia banks in 1994 as well as the presidential decree of the Compilation of Islamic Law in 1991 (the product, compilation of Islamic law, is a reference in Islamic courts regarding family matters). ${ }^{20}$ To be more convincing to the Islamists, he also performed pilgrimage to Mecca. Basically, the regime showed more public commitment to Islam than previous years.

The Regime take some other efforts to calm down the situation by establishing ICMI/Ikatan Cendekiawan Muslim Indonesia (The Indonesian Association of Muslim Intellectuals) in 1990 as well as an Islamic bank and insurance agency, Bank Muamalat Indonesia. Bank Muamalat

19 Ahmad Rizky Mardhatillah Umar, "Melacak Akar Radikalisme di Indonesia," Jurnal Ilmu Sosial dan Ilmu Politik, Volume 14, Issue 2 (November 2010), p. 175.

20 Melissa Crouch, Law and Religion in Indonesia: Conflict and the Courts in West Java (London: Routledge, 2011), p. 42. 
Indonesia campaigned its slogan as the first bank in Indonesia that was in accordance with sharia. This Bank was established as the initiative for establishment of many other Islamic sharia banks and insurance companies. In addition, other affirmative policies from government to gain sympathy from the Islamists are the establishment of the Abdi Bangsa Foundation, the Center of Information and Development Studies (CIDES) which is considered as the think-tank association as well as the Islamic daily newspaper Republike and Ummat as the educational media. $^{21}$

The establishment of ICMI in 1991 was actually an illustration of the 'accommodative' policy of Soeharto's regime in managing Indonesian Muslim community. This policy was aimed to please Muslim community with the expectation that they, in return, will express their sole loyalty toward the existing power holder. Unlike Komando Jihad who was depicted as terrorist and Islamist-radical, ICMI represents the picture of moderate Muslims who could function as a bridge between the regime and Muslim. In Indonesian political context, ICMI is a state corporatism model to primarily incorporate Muslim intellectuals and members of the new urban Muslim middle class. ${ }^{22}$ Many famous Muslim intellectuals joined this group; Amien Rais, Sri Bintang Pamungkas, Eggy Sudjana, Din Syamsudin and Adi Sasono. This is a new era wherein Islam finally had marked its time as a social and political force. In the euphoria, some may even saw it as a possible tool to strike back at those deemed responsible for Muslim oppression in the past. Despite its nature as state corporatism, ICMI has played a significant role in advocating the rise of pro-democracy discourse and even encouraged reformasi. Prominent figures within ICMI such as Amien Rais and Din Syamsuddin from Muhammadiyah and Sri Bintang Pamungkas militantly campaigned by calling for Soeharto's resignation from Presidency. Along with that, they also promoted democracy as the only way out from political and economic crisis that struck Asian countries in 1997. This financial crisis was followed with many mass protests and rallies in a variety of areas; on the roads, campuses, and mainly in the Parliament building. As a climax of the chaotic condition, Soeharto resigned from presidency on $21^{\text {st }}$ of May 1998.

21 Noorhadi Hasan, "Reformasi, Religious Diversity, and Islamic Radicalism after Suharto," Journal of Indonesian Social Sciences and Humanities, Volume 1 (2008), p. 45.

22 Ibid. 


\section{Reorganization of Islamic Political Power in post-New Order Era}

The fall of the authoritarian regime in 21 May 1998 has opened the door for Islamists to re-enter into Indonesia's politics. This was marked by the establishment of new Islamic political parties and their participation in the 1999 General Election. Many of new political parties adopted Islam as their ideological orientation and utilized Islam as their political linkage between parties, Muslim communities and the state as well as Islamic organizations and paramilitaries. This phenomenon is called "reorganizing power." The term of reorganizing power here is understood as strengthening the political influence of Islam in the political and social space in the society. It was indicated by political Islam advocates in Indonesia who have exerted two major streams to channel their Islamic aspirations and goals. ${ }^{23}$ Some of them have taken the legal and formal political approach in order to achieve their objective by establishing and/or joining in Islamic parties, like the Crescent and Moon Party (PBB) and the Justice and Prosperous Party (PK). Both parties explicitly declared Islam as their sole ideological basis and philosophy while the United Development Party (PPP) also rigorously shown its returning to Islam by putting the old symbol, the picture of ka'ba. ${ }^{24}$

The emergence of Islamic political parties in Indonesia's post-New Order encouraged Islamist constituency to revive debate on Piagam Jakarta (Jakarta Charter) especially on seven omitted words of 'dengan kewajiban menjalankan syariat bagi pemeluknya' as adherent obligation for Muslims. The emergence of the discourse of revitalization about the words was reaction of the New Order Regime's application of Pancasila as the sole ideology in many Islamic organizations. One of the consequences is the application of sharia (Islamic law) which was endorsed with the enactment of sharia bylaws (peraturan daerah/perda), on behalf of regional autonomy. In the context of regional autonomy in Indonesia, the enactment of sharia was introduced Aceh by forming qanun asasi as provincial bylaws based on Islamic values. ${ }^{25}$ Qanun Asasi

${ }^{23}$ Vedi R. Hadiz and Richard Robison, Reorganising Power in Indonesia: The Politics of Oligarchy in an Age of Markets (London: Routledge, 2005), p. 125.

24 Paul J. Carnegie, “The Politics of Indonesia's Islamic Identification," Dialogue, Volume 4, Issue 1 (2006), p. 12.

${ }^{25}$ Greg Fealy, "Islamic Radicalism in Indonesia: The Faltering Revival," Southeast Asian Affairs (2004), p. 115. 
contained moral rules should be obeyed by Acehnese such as regulations to compel Muslim women to adhere to Islamic dress codes, wearing the headscarf in public space and implementation of canning for the convicted fornication and stealing. This implementation of sharia in Aceh is followed by many regions especially in number of districts in West Java and several districts in South Sulawesi, including Maros, Gowa, and Bulukumba. These regions commonly emphasized Qur'an literacy for head district who want to compete for election, issued regional regulation to prohibit prostitution practice and restricting distribution of alcohol. ${ }^{26}$

Implementation of sharia as "Islamization" process in Indonesia is a sign of rising middle class seeking moral orientation and identity in a rapidly changing socio-political and economic environment. ${ }^{27}$ Sharia becomes main issue for the Islamists to put an end to so-called secular regime who had been repressive and oppressive. It was indicated by the political competition between Islamist and nationalist in the early period of Reformasi Era. The competition started since anti- Habibie demonstration emerged in November 1999, nationalist group worried. In addition to this issue, nationalists also questioned Habibie's commitment to eradicate corruption especially when his handling of corruption cases relating to Soeharto and his cronies did not fulfill people's expectation. The competition continues when the presidential election was held in 2004 wherein Megawati Soekarnoputri, the chairman of Partai Demokrasi Indonesia Perjuangan (Indonesia Democratic Party of Struggle) run for presidential nomination. Many Islamist organizations passed a recommendation that the president should be male according to Islamic injunctions. If Megawati were elected as president, Islamist would not accept her presidential office because of her gender and secular ideology.

Series of failure that Islamist political force experienced to establish Islamic state in Indonesia through formal political channels and eliminate influence of secular force in Indonesian politics triggered some Islamist to intensify extra-parliamentary strategy. Islamic militia groups emerged in response to that failure in formal political stage by using jihad ideology. Originally, jihad is defined as holy struggle against

${ }^{26}$ Wasisto Jati, "Permasalahan Implementasi Perda Syariah Dalam Otonomi Daerah," Al-Manahij, Volume 7, Issue 2 (2013), p. 8.

27 Angel M. Rabasa, Political Islam in Southeast Asia: Moderates, Radicals and Terrorists (London: Oxford University Press, 2003), p. 78. 
kafir people who rejects God or who hides, denies, or covers up the "truth." Nowadays, after the 9/11 incident, jihad has become one of the most controversial and misunderstood aspects of Islam. This term refers to Islamist person who believes that an Islamic state governing the entire community of Muslims must be created, and that this necessity justifies violent means against those who stand on its way. They also idealized martyrdom, which also has a meaning in Islamic history, as a way to fulfill religious duty. Newly won-over jihadists found great appeal in the romantic vision of dying a martyr's death. After Afghan-Soviet war, many radical Islamists came to believe that jihad never ends. Soviet occupation is one of Islamist' enemies, and American and Israeli's political influence in Arab also should be stopped. Those nations are categorized as "great Satan" for Islam now.

\section{"Jihad against the West": New Pattern of Islamic-Populism}

There are a variety of explanations for elucidate "jihad against the west" become the most prominent source of Islamic-radicalism in Indonesia. First, West and Jews have used their supremacy of global power in economic and military power to subordinate, exploit, and suppress the Islamic community (umat) in entire world. Radicals built conspiracy rhetoric blaming Zionist and Christian international powers for any economic inequality among nations in the world and believed in a worldwide the United States-led conspiracy and Israel to undermine and annihilate Muslim countries. Second, conditions of Muslims are morally degraded due to the influence of Western culture and far away from Islamic values. The most abrasive issues were New Project of New Worlds (NPNW) which perceives a covert conspiracy by Jews planning to rule and dominate the world through capitalism, communism, democratization, authoritarianism, revolution and economic liberalization, and atheism.

Whether right or not, NPWP is used by radicals as rhetoric paradigm against the West and Jews in many Muslim countries. According to the radicals, this chaotic situation can only be rectified by returning to the "pristine" Islam practiced by the founding generation of Muslim leaders with established global caliphate, Islamic state, and implementation of sharia as global law order. They believe that global caliphate will be the key to resolve Muslims' suffering inflicted by Jews and the West. Therefore, violent jihad is one only legitimate reason, obligatory as a holy war to defend Islam and establish global caliphate. The term holy war was generated in Europe during the Crusades 
episode. Nowadays, holy war as jihadist concept means struggle to eradicate the West as great Satan and reconstruct Islam back to early era wherein Islam was practiced by the prophet Muhammad and their Umma in Mecca and Medina. This desire to recap the true essence of early Islam is often labeled as "salafism", drawn from the Arabic term al-salaf al-salih or "righteous ancestors" who inherited knowledge of Islam directly from the Prophet Muhammad.

In order to address and legitimate these movements, radical groups adopted religious teaching from a medieval scholar affiliated to Hanbali school of law, Ibn Taymiya (1268-1328). He proposes a more active view of jihad to implement sharia and establish caliphate. This is a pretext to revive Muslims from backwardness. Ibn Taymiya's thoughts have heavily influenced Muslim extremists in the twentieth century, including the Muslim Brotherhood of Egypt and Osama bin Laden. They argue that Muslims' revival is potential to become a super power to challenge the hegemony of Zionist-Crusader international forces.

In many aspects, radical Islamism movement in Indonesia is strongly rooted in early Islamist and jihadist thinking from MiddleEastern connection. It was indicated by the emergence of many dozens of Islamist groups that have the closest ties with Islamist organization from the Middle East like Muslim Brotherhood, Mujahedeen Council, and many more. ${ }^{28}$ There are three analyses to investigating the emergence of contemporary Indonesian radical Islamism. The first is historical context of radical Islamism in Indonesia, its past connection to colonialism, as well as a more contemporary one to Middle Eastern Islamism. The second is resurgence within the larger context of global jihad movements; it traces the origins of the ideology of radicalism itself that dominates much of the discourse on the Israeli-Palestinian conflict in Arab countries. The Third is implementation of sharia as ideology of state which will be problem solver for the current crises and disasters afflicting Indonesia.

The West and Jewish sentiment still becomes main issue for many radical Islamism organizations in Indonesia, but not of all organizations are persistent with this issue. There are ramifications from main issue becoming sub-issue that used as main goals from organizations.

${ }^{28}$ Noorhaidi Hasan, Laskar Jihad: Islam, Militancy, and the Quest for Identity in Post-New Order Indonesia (Ithaca: SEAP Publication, 2006), p. 266. 
Table 1: Islamic Organization in Post-Soeharto Era and Its Political Issue $^{29}$

\begin{tabular}{|c|c|c|}
\hline Islamic Organization & Main Issue of Movement & Type of Action \\
\hline Hizbut Tahrir Indonesia & $\begin{array}{l}\text { Islamic State and Global } \\
\text { Caliphate }\end{array}$ & $\begin{array}{l}\text { Non-violent action } \\
\text { likes seminar, } \\
\text { demonstration, } \\
\text { socialization, etc. }\end{array}$ \\
\hline $\begin{array}{l}\text { Front Pembela Islam } \\
\text { (Islamic Defenders Front) }\end{array}$ & $\begin{array}{l}\text { Sharia implementation, but } \\
\text { doesn't command to } \\
\text { establish Islamic state }\end{array}$ & $\begin{array}{l}\text { Violent action likes } \\
\text { raid attack to night- } \\
\text { club and discotheque, } \\
\text { anti-apostasy } \\
\text { movement }\end{array}$ \\
\hline $\begin{array}{l}\text { Laskar Jihad } \\
\text { (Warriors of Jihad) }\end{array}$ & $\begin{array}{l}\text { Christianization Project and } \\
\text { West and Jewish conspiracy } \\
\text { in Indonesia }\end{array}$ & $\begin{array}{l}\text { Violent action likes } \\
\text { paramilitary attack in } \\
\text { conflict regions (Poso, } \\
\text { Maluku, Solo, etc) }\end{array}$ \\
\hline $\begin{array}{l}\text { Majelis Mujahidin } \\
\text { Indonesia (Indonesian } \\
\text { Islamic Warriors' Council) }\end{array}$ & $\begin{array}{l}\text { complete implementation } \\
\text { of sharia in Indonesia and } \\
\text { established Islamic state } \\
\text { and global caliphate }\end{array}$ & Violent action \\
\hline $\begin{array}{l}\text { Jammah Islamiyah } \\
\text { (Islamic community) }\end{array}$ & $\begin{array}{l}\text { Islamic State and Global } \\
\text { Caliphate }\end{array}$ & $\begin{array}{l}\text { Violent action likes } \\
\text { suicide bombing in } \\
\text { western linked } \\
\text { building and state } \\
\text { building, }\end{array}$ \\
\hline Hamas Indonesia & $\begin{array}{l}\text { Israeli-Palestinian conflict, } \\
\text { struggle for Palestinian } \\
\text { independence }\end{array}$ & Non Violent action \\
\hline
\end{tabular}

There are many issues of movement used by Islamist organizations in post-Soeharto Indonesia, which range from sharia, Islamic state, global caliphate, and many more. However, as previously mentioned radicalism is not only rooted from Islam-related issues. If we see carefully, the emergence of Islamist organizations is initially preceded by economic inequality and political marginalization. These two conditions are truly the onset of radical thought. Radical groups usually recruit many young people from desperate and poor families.

${ }^{29}$ Merlyna Lim, "Radical Islamism in Indonesia and Its Middle Eastern Connection," Meria Journal, Volume 15, Issue 2 (June 2011), p. 34. 
Uniquely, radicalism is driven by intellectual activists who actually belong to middle class. The transformation of jihadists from poor people to educated ones indicated that radicalism teaching had great influence on society. The process of radicalization in school happens from the earliest level to university level, through the process of indoctrination, which usually occurs through religious extracurricular activities in school and college. A survey report from Centre of Islamic Studies and Peace during October 2010 to January 2011 showed that 49 percent of students in Greater Jakarta (Jakarta, Bogor, Tangerang and Bekasi) tend to agree to take violent action to resolve the problem of religion and morality.

\section{Conclusion}

As this article has shown, Indonesia's contemporary radical Islamism is not compatible with security analysis which mainly addresses issues of terrorism and violence. Instead, it does represent a complex mixture of tradition, middle eastern-linkage, and revivalism. Radical Islamism is not just contemporary phenomenon, but it is deeply connected to local and global histories of Islamist movements. By putting Islamic-populism as main perspective, this article shows that radicalism emerged from the spirit of liberation to free from economic inequality and political marginalization. As happened in the case of Turkey and Egypt, Islamic radicalism emerged as influential political forces in post-authoritarian regimes. Radicalism in Indonesia also experienced similar features by relying on the strength of populist Muslims. Nevertheless, populism movement in Indonesia does not develop into a major political force due to strong influence of secular and nationalist politics in formal politics. Populist Islamic movement was radicalized by the failure in formal politics. Global caliphate, Islamic state, and the application of sharia are the goals of radical organizations in Indonesia today. However, it seems it will take time for Muslims populist forces to achieve their goals because of its use of extra parliament strategy, which is proven ineffective so far. []

\section{References}

\section{Books and Articles}

Barton, Greg. Indonesia's Struggle: Jemaah Islamiyah and the Soul of Islam. Sidney: University of New South Wales Press, 2004. 
-. "The Historical Development of Jihadi Islamist Thought in Indonesia." in Scott Helfstein (ed.). Radical Islamic Ideology in South East Asia. New York: South East Asia Research Press, 2011.

Baswedan, Anies Rasyid. "Political Islam in Indonesia - Present and Future Trajectory." Asian Survey, Volume 44, Issue 5 (2004): pp. 669-690.

Bruinessen, Martin van. "Genealogies of Islamic Radicalism in PostSoeharto Indonesia." South East Asia Research, 10 (2002): pp. 117-154.

Canovan, Margaret. Populism. New York and London: Harcourt Brace Jovanovich, 1981.

Carnegie, Paul J. "The Politics of Indonesia's Islamic Identification." Dialogue 4 (2006): pp. 1-30.

Crouch, Melissa. Law and Religion in Indonesia: Conflict and the Courts in West Java. London: Routledge, 2011.

Eliraz, Giora. Islam in Indonesia: Modernism, Radicalism, and the Middle East Dimension. Sussex: Sussex Publishers, 2004.

Fealy, Greg. "Islamic Radicalism in Indonesia: The Faltering Revival." Southeast Asian Affairs (2004): pp. 104-121.

Fischer, Michael. "Islam and The Revolt of Petit Bourgeoisie," Daedalus, (1982):pp.101-125.

Hadiwinata, Bob. Democracy in Indonesia: The Challenge of Consolidation. New York: Nomos Publishers, 2007

Heiduk, Felix. "Between a Rock and a Hard Place: Radical Islam in Post-Soeharto Indonesia." International Journal of Conflict and Violence 6 (2012): pp. 26-40.

Hadiz, Vedi R. "Indonesian Political Islam: Capitalist Development and the Legacies of the Cold War." Journal of Current Southeast Asian Affairs, 30 (2011): pp. 1-37.

Hadiz, Vedi R. and Richard Robison. Reorganising Power in Indonesia: The Politics of Oligarchy in an Age of Markets. London: Routledge, 2005.

Hasan, Noorhaidi. Laskar Jihad: Islam, Militancy, and the Quest for Identity in Post-New Order Indonesia. Ithaca: SEAP Publication, 2006. 
-. "Reformasi, Religious Diversity, and Islamic Radicalism after Soeharto." Journal of Indonesian Social Sciences and Humanities, 1 (2008): pp. 23-51.

Jati, Wasisto. "Permasalahan Implementasi Perda Syariah Dalam Otonomi Daerah," Al-Manahij, Volume 7, Issue 2 (2013), pp.114.

Lim, Merlyna. "Radical Islamism in Indonesia and Its Middle Eastern Connection.” Meria Joumal, 15 (2011): pp. 20-35.

Mujani, Saiful. Muslim Demokrat Islam, Budaya Demokrasi, dan Partisipasi Politik di Indonesia Pasca-Orde Baru. Jakarta: Gramedia, 2007.

Rohan, Gunaratna. Inside Al Qaeda: Global Network of Terror. New York: Columbia University Press, 2002.

Schumann, Olaf. "Jihad for Whom? The Radicalization of Religion as a Response to Political Oppression: From Turkish to Indonesian Islam." Journal of Indonesia Islam, 2 (2008): pp. 240-266.

Tugal, Cihan. "Islamism in Turkey: beyond instrument and meaning." Economy and Society, 31 (2002): pp. 85-111.

Rabasa, Angel M. Political Islam in Southeast Asia: Moderates, Radicals and Terrorists. London: Oxford University Press, 2003.

Umar, Ahmad Rizky Mardhatillah. "Melacak Akar Radikalisme di Indonesia." Jurnal Ilmu Sosial dan Ilmu Politik, 14 (2010): pp. 169186.

Wahid, Abdurrahman. Ilusi Negara Islam. Jakarta: Maarif and Wahid Institute, 2011.

Zeghal, Malika. "Religion and Politics in Egypt: The Ulama of AlAzhar, Radical Islam, and the State." International Journal of Middle East Studies, 31 (1999): pp. 371-399. 